\title{
THORACIC SURGERY CLINICS
}

\section{FORTHCOMING ISSUES}

February 2019

Surgery for Pulmonary Mycobacterial Disease

John D. Mitchell, Editor

\section{May 2019}

Thymectomy for Myasthenia Gravis Joshua R. Sonett, Editor

\section{August 2019}

Education and the Thoracic Surgeon

Edward D. Verrier, Editor

\section{RECENT ISSUES}

August 2018

Fundamentals of Airway Surgery, Part II Jean Deslauriers, Farid M. Shamji, and Bill Nelems, Editors

\section{May 2018}

Fundamentals of Airway Surgery, Part I Jean Deslauriers, Farid M. Shamji, and Bill Nelems, Editors

February 2018

Thoracic Surgery in the Special Care Patient Sharon Ben-Or, Editor

SERIES OF RELATED INTEREST

Surgical Clinics

available at: http://www.surgical.theclinics.com

Surgical Oncology Clinics

available at: http://www.surgonc.theclinics.com

Advances in Surgery

available at: http://www.advancessurgery.com 